\title{
砂州植生の分布形状を考慮した 伏流流動に伴う脱窒特性 DENITRIFICATION ACTIVITY THROUGH SUBSURFACE FLOW IN SANDBAR WITH VEGETATION
}

\author{
尾花まき子1・戸田祐嗣 2 ・辻本哲郎3・野尻晃平4 \\ Makiko OBANA, Yuji TODA, Tetsuro TSUJIMOTO and Kohei NOJIRI \\ 1正会員 MSCE 名古屋大学研究員 工学研究科（干464-8603 愛知県名古屋市千種区不老町） \\ 2正会員 博（工）名古屋大学准教授 工学研究科社会基盤工学専攻（†464-8603 愛知県名古屋市千種区不老町） \\ 3 フェロー会員 工博 名古屋大学教授 工学研究科社会基盤工学専攻（†464-8603 愛知県名古屋市千種区不老町） \\ 4名古屋大学大学院博士前期課程 工学研究科（†464-8603 愛知県名古屋市千種区不老町）
}

\begin{abstract}
River landscape with sandbar is composed of several elements such as vegetation, bare area, side-pool and so on. In recent years, it has been reported that sandbar (vegetation in particular) has water purification function, but the quantification of purification is still unknown. The purpose of this study is to examine how the nitrogen is trapped and retained by vegetation of sandbar through numerical calculation of subsurface flow based on field observation. The numerical simulation was performed under the discharge and the topographical conditions of the Yahagi river. The main results of this study are that the vegetation area of the sandbar has higher potential of denitrification than bare area. Also, it was clearly showed that the distribution of vegetation affected nitrogen dynamics. Thus, it has become possible to propose the effective distribution of vegetation for the maximization of the water purification function by using the numerical simulation.
\end{abstract}

Key Words : Denitrification activity, quantification, vegetation, sand bar, Yahagi river

\section{1. はじめに}

交互砂州河川の管理目標として挙げられている「砂州 景観の保全と整備」1)に向けて，砂州のどの場が砂州の 環境機能を発揮する上で重要であるのかを明確にするこ とは喫緊の課題である1). そこで，砂州景観の河川に対 する寄与の明確化が重要であると考え, 砂州が担う生態 系機能の一つである窒素・リンの除去といった水質浄化 を指標として取り上げる．ここでは，特に砂州伏流中の 窒素動態に着目し，伏流環境下での脱窒反応による窒素 の除去を水質浄化機能として定義する.

砂州の水質浄化に関わる窒素の硝化・脱窒反応につい て見ると, 種々の調査報告があり，表流水が砂州を伏流 する過程で, 微生物作用による有機物や無機態窒素の酸 化分解が確認されている2). 一方, 砂州景観は裸地域や 植生域などさらに小さなスケールの景観要素から構成さ れており, 景観要素と関連した土壌特性や比高の違いは

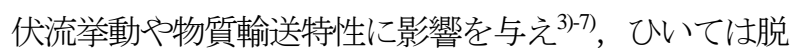
窒への寄与にも違いがあることが考えられる．著者らは 既往研究の中で, 水質浄化機能は砂州景観要素それぞれ の場が固有する『潜在性（ポテンシャル）』と，その時 その時の表流水や伏流水などの水理・水質環境によって 具体的に機能が発現する『フラックス』という二側面を 有し, 場の保全や再生に向けては双方のバランスへの着 目が重要であることを指摘している8). その中で，砂州 上の植生域においての脱窒ポテンシャルの卓越が明確に なっている7が，フラックスを考慮した水質浄化機能の 定量化にまでは至っておらず，それに関する他の研究事 例もほとんどみられない.

以上の背景から, 本研究では, 特に砂州上の植生域に 着目して, 伏流流動に伴う砂州の脱窒量を現地観測, 室 内実験および数值解析を援用して算出することを試みる. さらに，構築したモデルを用いて，砂州植生の分布形状 の違いが脱窒に与える影響も検討する. 


\section{2. 現地観測}

\section{（1）観測対象地および観測方法}

\section{a) 観測対象地の概要}

現地観測は，愛知県豊田市に位置する矢作川の河口よ り 14〜20km区間で実施した。図-1に示す矢作川は，流 路延長 $117 \mathrm{~km}$, 流域面積 $1,830 \mathrm{~km}^{2}$ の一級河川であり，そ の中・下流域部の流域に位置する豊田市，岡崎市には農 業・工業地域が広がっている。 これらの地域の治水と利 水のため, 矢作川本川の河口から34.6km地点から80.0km 地点の区間には7つのダムが建設されている.その中で 最下流に位置する明治用水（河口から34.6km地点）では, 灌激期に $30 \mathrm{~m}^{3} / \mathrm{s}$ の河川水の取水が行われ，それにより下 流側の河川流量を半減させている.この影響により，矢 作川の下流域では平水時の河川流量が小さく，水深の低 下，河床材料の移動頻度の低下などが生じているものと 判断される. 観測対象域は，支川の流入がなく河口から の塩分遡上の影響も受けない区間を対象としている.

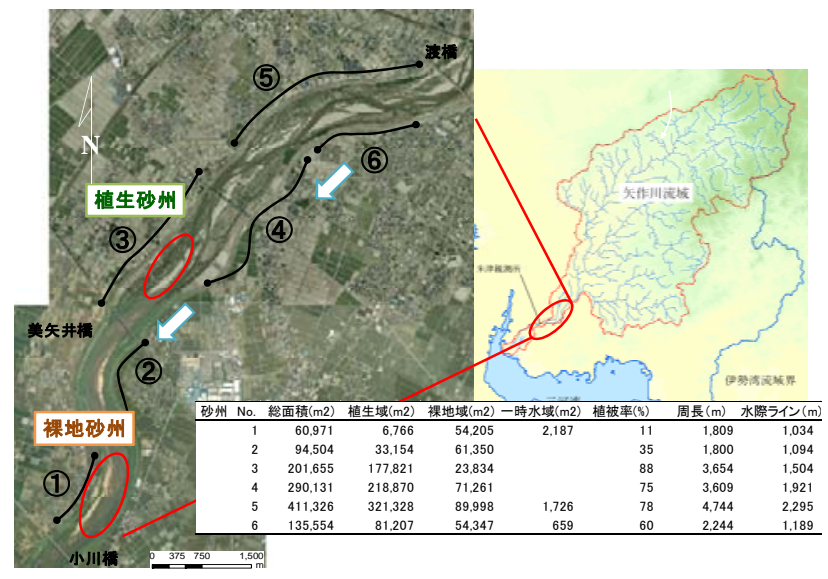

図-1 矢作川流域図と調査対象区間
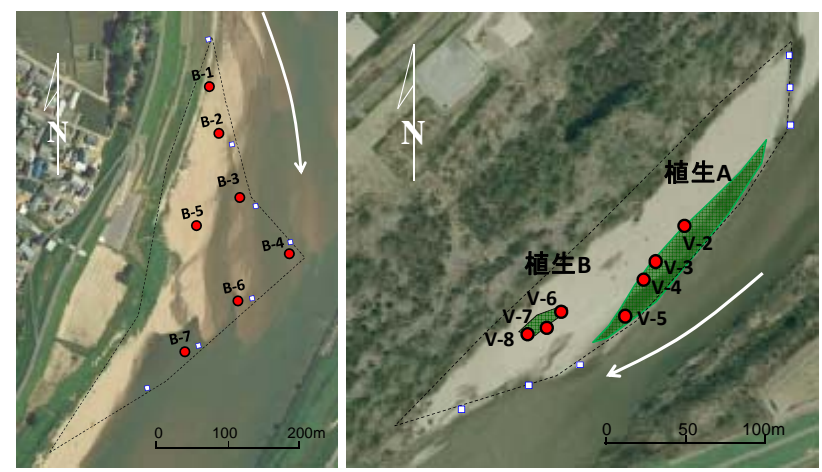

図-2 観測井戸位置図（左 : 裸地砂州, 右 : 植生砂州)

\section{b）観測方法}

はじめに，航空写真を用いて砂州の裸地域と植生域を 分類し，区間内の地形特性（砂州形状や周長），植被率 などをGIS解析によって算出した（図-1参照）。ここで は，植被率が35\%以下の砂州を「裸地砂州」，60\%以上
の砂州を「植生砂州」と定義する. 区間内で，裸地域と 植生域が各々卓越する砂州を選定し，各景観要素での伏 流水質や物理基盤条件を把握するために2009年8月19-20 日の平水時に現地観測を実施した。観測内容は，表流水 および伏流水の水位計測と採水を期間中36時間において 約3時間間隔にて行った. 図-2に示す各砂州で埋設した 簡易井戸から伏流水を採水し, 多項目水質計

（YSI/Nanotech556）を用いて伏流水温, pH，溶存酸素 量, 酸化還元電位を測定した。また，冷蔵保管して持ち 帰ったサンプリング試料（表流水・伏流水・土壌）を室 内実験により分析し, 物理基盤条件 (粒度, 透水係数, 水分保持特性）と水質項目（各態窒素，溶存態有機炭素， 全窒素）の各濃度を定量した。

砂州土壌については，検土杖を用いて土質の鉛直構造 を計測し，表層・表層下 $1 \mathrm{~m} の 土$ 土壤を採取した。各々を JISA1204に基づいて粒度試験に供したほか，定水位透水 試験にて透水係数を算定した. 水質分析には，水質分析 計（SWAAT, BLTEC），全有機炭素計（TOC-V CPH,島 津製作所）および全窒素計（TNM-1,島津製作所）をそ れぞれ用いた。

なお，本研究では，裸地域と植生域の環境条件の違い を顕著に捉えるために，基盤情報について裸地砂州で得 られた結果を裸地域の代表值として用い，植生砂州で得 られた結果を植生域の代表值として用いることとする.

\section{（2）観測結果}

各景観要素での表層および表層下 $1 \mathrm{~m} の 土$ 土壌粒度分布 特性と透水係数を表-1に示す，裸地域は主に粗砂，植生 域は中砂から構成されており，比較的分級された土であ ることが分かる. 土堙の鉛直構造は，観測地点のGL$1.2 \mathrm{~m}$ 付近には粘土からなる難透水層が広がっていること と伏流水面はその直上のGL-1.0m付近を流下しているこ とを確認した。透水係数は，各景観要素での粒径による 違いが見られ，この違いが伏流流動の速度差に大きく影 響していると考えられる。また，実験で得た值のほかに， 経験式（Hazen式 $k=D_{10}{ }^{2}(\mathrm{~cm} / \mathrm{s})$ ）を用いて算出した透水係 数の值も下表に併記する.

表-1 各景観要素での粒度分布と透水係数

\begin{tabular}{c|cc|cc}
\hline & \multicolumn{2}{|c|}{ 裸地域 } & \multicolumn{2}{c}{ 植生域 } \\
& $G L$ & $G L-1.0 m$ & $G L$ & $G L-1.0 m$ \\
\hline \hline 有効粈径 $D_{50}(\mathrm{~mm})$ & 1.01 & 1.70 & 0.38 & 0.20 \\
有效粒径 $D_{10}(\mathrm{~mm})$ & 0.53 & 0.71 & 0.19 & 0.20 \\
均等係数 $U_{C}$ & 1.92 & 2.96 & 2.15 & 3.54 \\
\hline \hline Hazen式による & & & & \\
透水係数 $k(\mathrm{~cm} / \mathrm{s})$ & 0.2 & 0.5 & 0.03 & 0.02 \\
実験值 $k(\mathrm{~cm} / \mathrm{s})$ & & & & \\
\hline Average $(\mathrm{cm} / \mathrm{s})$ & 0.8 & - & 0.02 & - \\
\hline
\end{tabular}


表-2 各砂州での伏流水質

\begin{tabular}{|c|c|c|c|c|c|c|c|c|c|}
\hline & $\begin{array}{c}\mathrm{DO} \\
(\mathrm{mg} / \mathrm{l})\end{array}$ & $\begin{array}{l}\mathrm{DOC} \\
(\mathrm{mg} / \mathrm{l})\end{array}$ & $\begin{array}{l}\mathrm{DON} \\
(\mathrm{mg} / \mathrm{l})\end{array}$ & $\begin{array}{c}\mathrm{TN} \\
(\mathrm{mg} / \mathrm{l})\end{array}$ & $\begin{array}{l}\text { 水温 } \\
\left({ }^{\circ} \mathrm{C}\right)\end{array}$ & $\begin{array}{l}\text { ORP } \\
(\mathrm{mV})\end{array}$ & $\mathrm{pH}$ & $\begin{array}{c}\mathrm{NO} 3-\mathrm{N}+\mathrm{NO} 2-\mathrm{N} \\
(\mathrm{mg} / \mathrm{l})\end{array}$ & $\begin{array}{l}\mathrm{NH} 4-\mathrm{N} \\
(\mathrm{mg} / \mathrm{l})\end{array}$ \\
\hline 植生砂州 & $\begin{array}{c}2.0 \\
(1.6 \ldots 3.5)\end{array}$ & $\begin{array}{c}1.5 \\
(0.9 \ldots 2.0)\end{array}$ & $\begin{array}{c}0.08 \\
(0.02 \ldots 0.14)\end{array}$ & $\begin{array}{c}0.21 \\
(0.08 \ldots 0.35)\end{array}$ & $\begin{array}{c}26.3 \\
(20.9 \ldots 27.3)\end{array}$ & $\begin{array}{c}-40.5 \\
(-174.6 \ldots 43.7)\end{array}$ & 6.2 & $\begin{array}{c}0.09 \\
(0.01 \ldots 0.3)\end{array}$ & $\begin{array}{c}0.04 \\
(0.005 \ldots 0.2)\end{array}$ \\
\hline 裸地砂州 & $\begin{array}{c}4.0 \\
(2.7 \ldots 5.0)\end{array}$ & $\begin{array}{c}0.75 \\
(0.6 \ldots 1.1)\end{array}$ & $\begin{array}{c}0.04 \\
(0.02 \ldots 0.07)\end{array}$ & $\begin{array}{c}0.35 \\
(0.07 \ldots 0.8)\end{array}$ & $\begin{array}{c}27.7 \\
(26.7 \ldots 28.8)\end{array}$ & $\begin{array}{c}96.4 \\
(39.4 \ldots 113.6)\end{array}$ & 6.6 & $\begin{array}{c}0.30 \\
(0.06 \ldots 0.8)\end{array}$ & $\begin{array}{c}0.01 \\
(0.002 \ldots 0.01)\end{array}$ \\
\hline
\end{tabular}

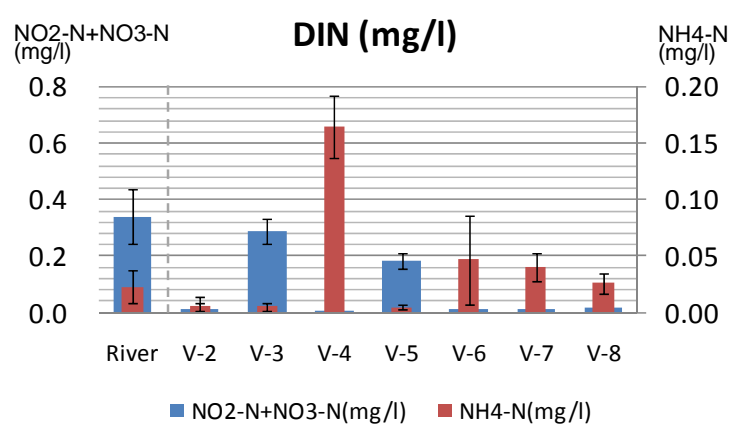

図-3＼cjkstart植生砂州での伏流水濃度空間分布

各水質項目の砂州ごとの平均值を表-2に示す（括弧内 は最小值と最大值）。各砂州での濃度を比較した結果, 二者は異なる特性を有していることが明らかになった。 還元的な場であることを示寸指標であるORPや溶存酸素 量は植生域で顕著に低い，また，脱窒反応に直接的に関 与寸るDOC濃度が高い理由は, 植生による有機物の供給 が考えられる. $\mathrm{pH}$ と水温は, 脱窒反応を担う微生物の 活動に至適性を有するが，観測值はいずれも微生物が活 発に活動できる範囲内に収まっている，図-3に，次章の 解析場として対象とする植生砂州での濃度の空間分布を 示す. Riverは, 植生砂州上流側での表流水質である. 表流水濃度と比較すると, 平均的な窒素総量は減少して いることが分かる．また，裸地砂州ではほとんど検出さ れなかったアンモニア態窒素が硝酸態窒素の存在量を上 回っている箇所が見られる.

以上より, 裸地域と植生域では， ORP，DO，DOC， 水温やpHなどの水質浄化に関与寸る環境因子に特徵的 な違いが見られることが明らかになった，特に，植生域 はORP，DOが顕著に低く還元的な環境であり，また DOCも高いため, 脱窒菌の活動を促進する条件が整って いることが示唆された.

\section{3. 数值解析}

本研究では, 砂州伏流に伴う窒素除去能を定量化する ため, 伏流水流動と伏流に伴う窒素の形態変化に関する 数值解析を実施した. 解析は, 伏流水流動解析と物質輸 送解析より構成される.

\section{（1）伏流水流動解析}

砂州内部の伏流水を不圧地下水流れとし，平面二次元
解析を実施した。解析対象地の矢作川下流部において, 検土杖を用いて土質の鉛直構造を計測した結果，砂州伏 流水水位より $1 \mathrm{~m}$ 程度下方に難透水性粘土層がほぼ水平 に存在し, その上部に比較的均質な帯水層が存在してい る. このため解析では, 水平な下端難透水層上の伏流流 動に対して, Dupuit-Forchheimerの仮定が成立するものと して，浸透層に関して鉛直積分された次式を用いて流動 解析を行った.

$$
\lambda \frac{\partial h}{\partial t}=\frac{\partial}{\partial x}\left(k h \frac{\partial h}{\partial x}\right)+\frac{\partial}{\partial y}\left(k h \frac{\partial h}{\partial y}\right)
$$

ここに, $h$ : 地下水位, $\lambda$ : 間隙率, $k$ : 透水係数である.

\section{（2）物質輸送解析}

本解析で考慮した砂州伏流流動中の窒素循環過程を図 -4に示す. 解析対象とする窒素の形態としては, 無機態 の窒素態である, アンモニアイオン, 硝酸イオン, 亜 硝酸イオンとし，それぞれの窒素当量濃度を $C_{\mathrm{NH} 4 \mathrm{~N}}, C_{\mathrm{NO}-}$ ${ }_{\mathrm{N}}, C_{\mathrm{NO2-N}}$ と記すこととする.

砂州伏流水流動中における微生物反応を考慮した無機 態窒素濃度 $\left(C_{\mathrm{NH} 4 \mathrm{~N}}, C_{\mathrm{NO}-\mathrm{N}}, C_{\mathrm{NO} 2-\mathrm{N}}\right)$ に関する移流分散方 程式は，以下のとおりである.

$\frac{\partial C_{i}}{\partial t}+u \frac{\partial C_{i}}{\partial x}+v \frac{\partial C_{i}}{\partial y}=\frac{\partial}{\partial x}\left(D \frac{\partial C_{i}}{\partial x}\right)+\frac{\partial}{\partial y}\left(D \frac{\partial C_{i}}{\partial y}\right)+R_{i}$

ここに, $u, v$ : 浸透層鉛直平均流速, $D:$ 分散係数, $R_{i}$ : 生物化学反応項である. 下付添字 $i$ 窒素3態 $\left(\mathrm{NH}_{4^{-}}\right.$ $\left.\mathrm{N}, \mathrm{NO}_{3}-\mathrm{N}, \mathrm{NO}_{2}-\mathrm{N}\right)$ の別を表わ寸指標である. 生物化

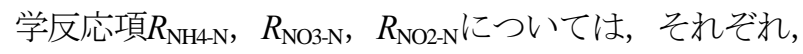
図-4中の黒矢印で示した生物化学反応の組み合わせによ り以下となる。

$$
\begin{aligned}
& R_{\mathrm{NH} 4-\mathrm{N}}=R_{\mathrm{DNH} 4}-R_{\mathrm{NS}} \\
& R_{\mathrm{NO} 3-\mathrm{N}}=R_{\mathrm{NB}}-R_{\mathrm{DA}} \\
& R_{\mathrm{NO} 2-\mathrm{N}}=R_{\mathrm{NS}}-R_{\mathrm{NB}}+R_{\mathrm{DA}}-R_{\mathrm{DI}}
\end{aligned}
$$

ここに, $R_{\mathrm{DNH} 4}$ : 脱アミノ反応速度, $R_{\mathrm{NS}}$ : アンモニア酸 化速度, $R_{\mathrm{NB}}$ : 亜硝酸酸化速度, $R_{\mathrm{DA}}$ : 硝酸還元速度, $R_{\mathrm{DI}}$ : 亜硝酸還元 (脱窒) 速度であり, それぞれ以下の ように定式化される.

$$
R_{\mathrm{DNH} 4}=k_{\mathrm{DON}} \cdot \mathrm{NH} 4 \cdot C_{\mathrm{DON}} \cdot X_{\mathrm{H}}
$$




$$
\begin{array}{r}
R_{\mathrm{NS}}=\frac{1}{Y_{\mathrm{NS}}} \mu_{\mathrm{NS}} \cdot \frac{C_{\mathrm{DO}}}{K_{\mathrm{S} \cdot \mathrm{NS} \cdot \mathrm{DO}}+C_{\mathrm{DO}}} \cdot X_{\mathrm{NS}} \cdot \frac{C_{\mathrm{NH} 4}}{K_{\mathrm{S} \cdot \mathrm{NS} \cdot \mathrm{NH} 4}+C_{\mathrm{NH} 4}} \\
R_{\mathrm{NB}}=\frac{1}{Y_{\mathrm{NB}}} \mu_{\mathrm{NB}} \cdot \frac{C_{\mathrm{DO}}}{K_{\mathrm{S} \cdot \mathrm{NB} \cdot \mathrm{DO}}+C_{\mathrm{DO}}} \cdot X_{\mathrm{NB}} \cdot \frac{C_{\mathrm{NO} 2}}{K_{\mathrm{S} \cdot \mathrm{NB} \cdot \mathrm{NO} 2}+C_{\mathrm{NO} 2}} \\
R_{\mathrm{DA}}=\frac{1}{Y_{\mathrm{DA}}} \mu_{\mathrm{DA}} \cdot\left(1-\frac{C_{\mathrm{DO}}}{K_{\mathrm{S} \cdot \mathrm{DA} \cdot \mathrm{DO}}+C_{\mathrm{DO}}}\right)\left(\frac{C_{\mathrm{DOC}}}{K_{\mathrm{S} \cdot \mathrm{DA} \cdot \mathrm{DOC}}+C_{\mathrm{DOC}}}\right) . \\
X_{\mathrm{DI}} \cdot \frac{C_{\mathrm{NO} 3}}{K_{\mathrm{S} \cdot \mathrm{DA} \cdot \mathrm{NO} 3}+C_{\mathrm{NO} 3}}=\frac{1}{Y_{\mathrm{DI}}} \mu_{\mathrm{DI}} \cdot\left(1-\frac{C_{\mathrm{DO}}}{K_{\mathrm{S} \cdot \mathrm{DI} \cdot \mathrm{DO}}+C_{\mathrm{DO}}}\right)\left(\frac{C_{\mathrm{DOC}}}{K_{\mathrm{S} \cdot \mathrm{DI} \cdot \mathrm{DOC}}+C_{\mathrm{DOC}}}\right) . \\
X_{\mathrm{DI}} \cdot \frac{C_{\mathrm{NO} 2}}{K_{\mathrm{S} \cdot \mathrm{DI} \cdot \mathrm{NO} 2}+C_{\mathrm{NO} 2}}
\end{array}
$$

ここに, $Y$ : 菌体収率, $\mu$ : 比増殖速度, $X$ : 菌体濃度,

$K_{\mathrm{S}}$ : 半飽和定数, $k$ : 加水分解速度であり, 下付添字に ついて, DNH4 : 脱アミノ反応, NS : アンモニア酸化, NB : 亜硝酸酸化, DA : 硝酸還元, DI : 亜硝酸還元, NH4 : アンモニウムイオン, DO : 溶存酸素, NO2 : 亜 硝酸イオン, NO3 : 硝酸イオン, DOC : 溶存態有機炭素, $\mathrm{DON}$ : 溶解性有機窒素, $\mathrm{H}$ : 通性嫌気性細菌を示す.

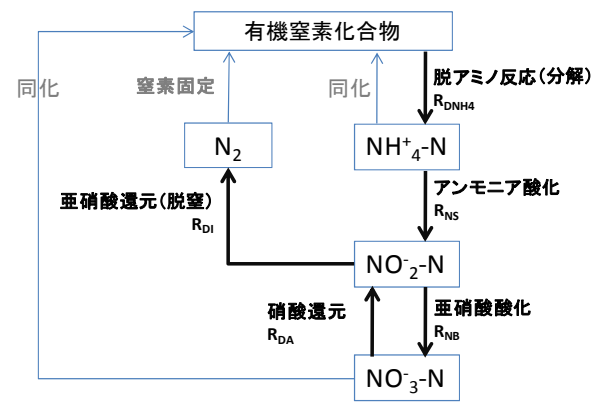

図-4 窒素循環過程

\section{（4）解析条件}

流動解析における境界条件について，河川水域との境 界部では，河川水位を与え，砂州陸側との境界部におい ては，横断方向の水位勾配をゼロとした．物質輸送解析 における境界条件については，河川から砂州側一伏流水 が流入する部分においては河川水質值 $C_{\mathrm{NH} 4 \mathrm{~N}}=0.023(\mathrm{mg} / \mathrm{l})$, $C_{\mathrm{NO}-\mathrm{N}+\mathrm{NO2}-\mathrm{N}}=0.34(\mathrm{mg} / \mathrm{l})$ を与え, 砂州から河川へ流出する 部分については，流出方向への濃度勾配をゼロとし，砂 州陸側との境界部分においては横断方向の濃度勾配をゼ ロとした．解析で用いた透水係数は，現地観測結果に基 づき裸地域，植生域でそれぞれ $k=5.0 \times 10^{-3}(\mathrm{~m} / \mathrm{s}), 2.0 \times$ $10^{-5}(\mathrm{~m} / \mathrm{s})$ とした. 生物化学反応に関するパラメータは, 前章において裸地域や植生域といった景観要素に依存す ると推定された溶存酸素濃度，溶存有機炭素濃度，溶解 性有機窒素濃度については，現地観測で得られた各々の 平均值を用いて，砂州全体一空間分布させた。これらを 表-3にとりまとめて示す. その他のパラメータである土 壌中の菌体濃度や微生物増殖速度などについては，文献

\begin{tabular}{|c|c|c|c|c|c|c|}
\hline & $R_{\mathrm{DNH} 4}$ & $R_{\mathrm{NS}}$ & $R_{\mathrm{NB}}$ & $R_{\mathrm{DA}}$ & $R_{\mathrm{DI}}$ & 出典 \\
\hline$X(\mathrm{mg} / \mathrm{l})$ & 0.50 & 0.30 & 0.10 & 1.0 & 3.0 & 宗宮9) \\
\hline$Y$ (mg.cell/mg) & & 0.13 & 0.05 & 0.60 & 0.72 & 楠田 ${ }^{10)}$ \\
\hline$\mu\left(\mathrm{s}^{-1}\right)$ & & $\begin{array}{c}5.3 \\
\times 10^{-6} \\
\end{array}$ & $\begin{array}{c}8.3 \\
\times 10^{-6} \\
\end{array}$ & $\begin{array}{c}1.1 \\
\times 10^{-5} \\
\end{array}$ & $\begin{array}{c}2.0 \\
\times 10^{-4} \\
\end{array}$ & 楠田 ${ }^{10)}$ \\
\hline$K_{\mathrm{S}}(\mathrm{mg} / \mathrm{l})$ & & 5.0 & $\begin{array}{c}5.0 \\
\times 10^{4} \\
\end{array}$ & $\begin{array}{c}1.0 \\
\times 10^{-3} \\
\end{array}$ & $\begin{array}{c}5.0 \\
\times 10^{-4} \\
\end{array}$ & $\begin{array}{l}\left.\text { 楠田 }{ }^{10}\right) \\
\text { 仮定値 }\end{array}$ \\
\hline$K_{\mathrm{S} \cdot \mathrm{DO}} \quad(\mathrm{mg} / \mathrm{l})$ & & 0.20 & 0.20 & 0.20 & 0.20 & 楠田 ${ }^{10)}$ \\
\hline$K_{\text {S.DOC }}(\mathrm{mg} / \mathrm{l})$ & & & & 0.70 & 9.0 & 仮定値 \\
\hline$k(\mathrm{l} / \mathrm{mg} / \mathrm{s})$ & $\begin{array}{c}2.2 \times \\
10^{-7} \\
\end{array}$ & & & & & 楠田 ${ }^{10)}$ \\
\hline
\end{tabular}
值を参考に決めざるを得ないが，これらについては裸地 域と植生域で同じ值を与えた（表-4参照）。
表-3 解析で用いた有機物及び酸素濃度

\begin{tabular}{rccc}
\hline & $C_{\mathrm{DON}}$ & $C_{\mathrm{DOC}}$ & $C_{\mathrm{DO}}$ \\
\hline \hline 裸地域 & 0.04 & 0.75 & 4.0 \\
植生域 & 0.08 & 1.5 & 2.0 \\
\hline
\end{tabular}

表-4 解析に用いた生物化学反応パラメータ

砂州地形および植生分布形状については，表-5に示す 6ケースを準備した。砂州地形は，矢作川での現地観測 対象とした植生砂州地形を与えた. Case1では，砂州上 の植生の有無がどのように脱窒へ影響するかを見るため, Case2では，植被率を30\%に固定した植生域の空間分布 の仕方の違いによる脱窒への影響を見るための計算条件 とした.

Case1-1は，観測対象である矢作川の植生砂州（図2）の植生分布を与え，モデルの検証に用いる. Case1-2 および1-3は，1-1の地形条件を保持したまま裸地のみの 場合と全面を植生で覆われた場合として与えた. 他方, Case2においては，植生分布形状の考慮の際に砂州形状 と植生繁茂についての関係性を調べた既往研究11)を参考 に，砂州における代表的な植生分布を選定した. Case2-

\begin{tabular}{|c|c|c|c|}
\hline Case & $1-1$ & $1-2$ & $1-3$ \\
\hline $\begin{array}{c}\text { 植被率 } \\
(\%) \\
\end{array}$ & 30 & 0 & 100 \\
\hline $\begin{array}{c}\text { 砂州面積 } \\
\left(\mathrm{m}^{2}\right)\end{array}$ & 4,875 & 4,875 & 4,875 \\
\hline Case & $2-1$ & $2-2$ & $2-3$ \\
\hline $\begin{array}{c}\text { 植被率 } \\
(\%)\end{array}$ & 30 & 30 & 30 \\
\hline $\begin{array}{c}\text { 砂州面積 } \\
\left(\mathrm{m}^{2}\right)\end{array}$ & 4,875 & 4,875 & 4,875 \\
\hline
\end{tabular}
1は 堤防側に植生が占有する場合，2-2は砂州上流側の 水際, Case2-3は砂州下流側水際部分にそれぞれ植生が 繁茂する場合である。

\section{表-5 解析ケース (緑部分 : 植生, 図下方直線 : 堤防, 表流水} は左から右へ流れるものとする. ) 


\section{4. 解析結果と考察}

\section{（1）モデルの検証と考察}

図-5に，解析対象とした植生砂州における無機態窒素 濃度の観測值と解析值との比較を示す．観測結果では, 表流水濃度より硝酸態窒素濃度が低く，アンモニア態窒 素濃度が高いことに対して, 計算值はその概ねの傾向を 表現できている，しかし，各物質濃度の増減の傾向を捉 えているものの, 砂州内の空間分布における微小変化ま では詳述できていない. この原因として，解析では，局 所的な地形特性の違いから生じる複雑な流動特性や水位 変動のみならず, 土壌粒子によるろ過, 沈殿や吸脱着な どの物理化学的作用を考慮していないことが考えられる。

以上から，解析では現実の砂州内の物質濃度の局所変 化を確実に再現するまでには至っていないが，本研究で 着目している景観要素の違いに応じた伏流流動特性や微 生物反応による各態窒素の濃度変化の傾向は捉えられて いるものと判断した. よって, 次節では本解析モデルを 用いて植生分布形状の違いが水質浄化機能に与える影響 について議論することとする.

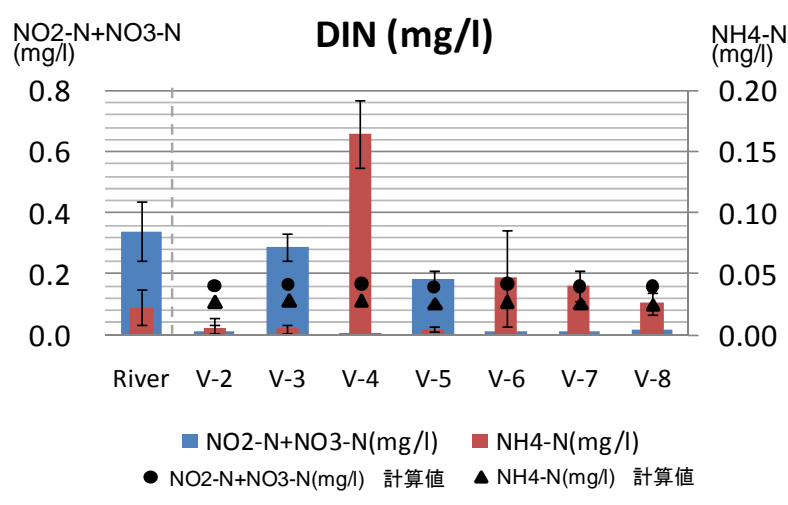

図-5＼cjkstart植生砂州観測地点での計算值と観測値

\section{（2）各ケースの結果と考察}

各ケースで算出した砂州全体での1日あたりの脱窒量 と単位面積当たりの脱窒速度を表-6に示す。また, 各 ケースにおける脱窒量の空間分布コンターを図-6に示す.

\section{a） Case 1:植生の有無による脱窒量の違い}

Case1-2の裸地のみの砂州（植被率0\%）とCase1-3の植 生の夕砂州（植被率100\%）の脱窒量を比較すると，植 生のみの砂州は裸地のみの砂州より3倍程度の脱窒量を 有することが明らかになると同時に，たとえ植被率が 0\%であっても脱窒反応は少なからず働いていることが 分かる.

次に，裸地のみの砂州（Case1-2）を基準として, Case1-1およびCase1-3の脱窒量を比較する．植被率の拡 大に伴う脱窒量は，線形的に増加していないことが見て とれる. 図-6のコンター図を見ても，砂州上流側におい て機能が高いことを示している. Case1の中で，唯一植 生が分布しているCase1-1では，上流側水際の植生部分
が多くの脱空機能を担っていることが分かり，下流側の 小さな植生群落も脱窒機能は発現しているものの水際植 生よりも役割は小さいことが図示されている。このよう な結果を総合すると，伏流水のフラックスによる物質の 移流・分散が, 同じポテンシャルを有する植生域におけ る浄化機能の発現における差異を生みだしていることが 分かる.

最後に，各3ケースで得られた脱窒速度を，干潟にお いて調査された脱窒速度と比較をしてみた. 本研究で得 られた2.2-6.6 (mg/m²/day)という值は，干潟域で既往研究 から報告されている 值 $13-236\left(\mathrm{mg} / \mathrm{m}^{2} / \mathrm{day}\right)^{12)}$, $3.6\left(\mathrm{mg} / \mathrm{m}^{2} / \text { day }\right)^{13)}$, 15-22 (mg/m²/day) ${ }^{14)}$ と比べて, 若干小 さめではあるが，オーダ一的には等しいレベルにあるこ とが分かった。

\section{b） Case2:植生分布を考慮した脱窒量の比較}

Case2での植被率30\%は，現地地形の植被率Case1-1と 等しくなるよう設定した. Case1-1の植生分布における 脱窒量18.0 (g/day)を基準に，それとの比較から検討を進 める.まず，3ケースを比較して明らかなことは，同じ 植被率にもかかわらず，植生分布によって脱窒量に違い が生じていることである. 水際上流部に植生が点在して いる場合が脱窒量の最大值を示している一方，水際下流 部に植生がある場合が最小值を示し，その差は1.0 (mg/m²/day)にのぼる. 二者をコンター図と合わせて考察 すると，伏流水流入口のある砂州上流側は脱窒反応に寄 与する基質因子が豊富に存在し, 脱窒機能の担い場とし て効果的な場と言える. 同じ水際にある植生でも下流側 植生の機能が低いことは，伏流水が砂州を流動する過程 で脱窒能を律速する基質因子が低减されているためであ る. 次に，水際中ほどに植生があるCase1-1と堤防側に 植生があるCase2-1を比較する. やはり水際での機能の 卓越を示す結果を見ると, 表流水と伏流水との水交換に よって脱窒の基質因子が供給されることが機能の発現に 差異を生んでいることが分かる.

c) まとめ

上述した結果によって，1) 砂州という場はたとえ裸 地のみであっても脱窒機能を担うこと，2) 植生分布の 違いは，アウトプットとしての脱窒量に影響を与え，そ れらは機能発現の強弱と直結していること，が明らかに なった. また，コンター眓によって景観要素の空間分布 の違いが与える機能発現の強弱を明示することができた.

表-6 各ケースでの脱窒量と脱窒速度

\begin{tabular}{ccc}
\hline & 脱窒量 $(\mathrm{g} / \mathrm{day})$ & 脱窒速度 $\left(\mathrm{mg} / \mathrm{m}^{2} /\right.$ day $)$ \\
\hline \hline Case1-1 & 18.0 & 3.7 \\
Case1-2 & 10.6 & 2.2 \\
Case1-3 & 32.1 & 6.6 \\
\hline \hline Case2-1 & 16.5 & 3.4 \\
Case2-2 & 18.7 & 3.8 \\
Case2-3 & 13.6 & 2.8 \\
\hline
\end{tabular}




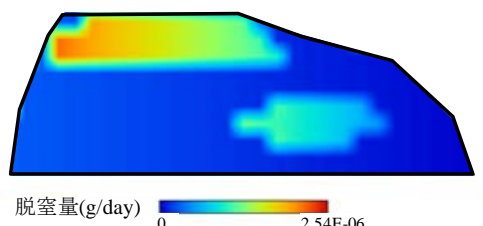

Case 1-1

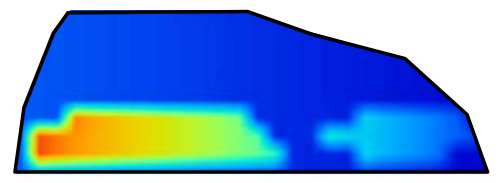

脱窒量(g/day)

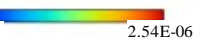

Case 2-1

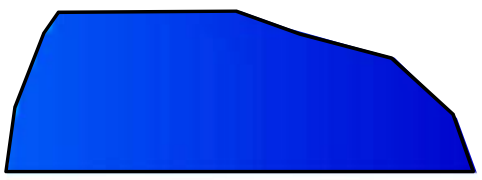

脱窒量(g/day) 0

Case 1-2

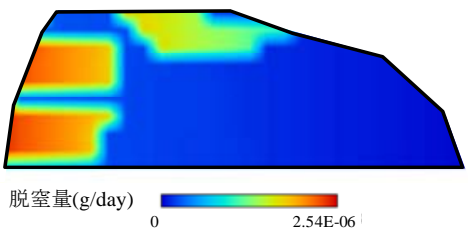

Case 2-2

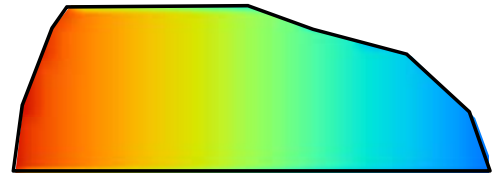

脱空量(g/day)

Case 1-3

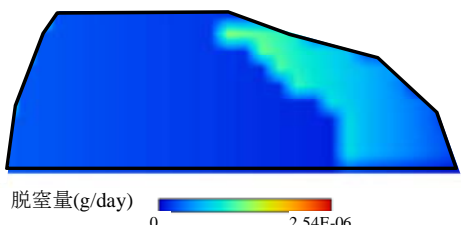

Case 2-3

図-6＼cjkstart各Caseでの脱窒量の空間分布コンター

\section{5. おわりに}

本研究では，特に砂州上植生に着目して，伏流流動に 伴う砂州の脱窒量を定量できる物質循環モデルを，現地 観測結果に基づいて構築した，植生の空間分布特性を自 在に変更できるモデルであるため，これを用いて，砂州 植生の分布形状の違いが脱窒量に与える影響を定量した。 砂州景観管理の視点に立つと，コンター図として機能 が発現している場の強弱を明示できたことは，管理への これらの結果の活用には効果的である. たとえば，河道 内植生の伐採・保全計画への活用の際には，水質浄化機 能を指標として見た場合, 平水時において機能が発現し ている場は保全優先場となるだろう。ただ，その際に始 めに述べたポテンシャルへの着目も忘れてはならないが, それら二側面のバランスを考えていくためのツールを構 築できたといってよい.

今後の課題としては，砂州内部で生起するさらなるメ カニズムの詳述を進めるとともに，河川本川に対する砂 州の役割の明確化に向けて, 河川構造により駆動される 伏流フラックス量に対する砂州の応答についても検討し ていきたい.

謝辞 : 本研究は文部科学省科学技術振興調整費「伊勢湾 流域圏の自然共生型環境管理技術開発（代表 : 辻本哲 郎）」の補助を受けて実施した. 水質分析においては, 東京理科大学の二瓶康雄准教授, 山口大学の赤松良久准 教授および名古屋大学の安佛かおり博士に一方ならぬご 協力を頂きました．記して謝意を表します。

\section{参考文献}

1) 辻本哲郎 : 砂州景観保全を河川生態工学からどう意義づける か, 河川技術論文集, 第10巻, pp.43-48, 2004.

2) 対馬孝治, 上田眞吾, 小倉紀雄 : 多摩川永田地区河川敷地下
水における無機態窒素の動態, 地球科学, 第36巻, pp.15-22, 2002.

3) 中島治美, 鷲見哲也, 辻本哲郎 : 木津川裸地における伏流水 の水質特性，河川技術論文集，第10巻，pp.381-386, 2004.

4) 鷲見哲也，恒川明伸，辻本哲郎：木津川砂州における植物生 育場の表層物理環境と物質輸送特性に関する研究，河川技術 論文集，第9巻，pp.389-394, 2003.

5) 片貝武史, 亀井丈史, 熟見哲也, 辻本哲郎 : 木津川植生砂州 における伏流水輸送と窒素動態, 河川技術論文集, 第12巻, pp.489-494, 2006.

6) Jeremy B. Jones and Patrick J. Mulholland: Streams and ground waters, pp.154-165, 2000.

7) 中島拓男 : 木津川調查対象砂州の細菌分布と脱窒活性, 木津 川の総合研究, pp.145-156, 2003.

8) 尾花まき子, 安佛かおり, 辻本哲郎 : 交互砂州河川の生態系 サービスポテンシャル評価の試み，河川技術論文集，Vol.16， pp.471-476, 2010.

9) 宗宮功 : 自然の浄化機構, 技報堂出版, pp.164-168, 1990.

10) 楠田哲也：自然の浄化機構の強化と制御, 技報堂出版, pp.6-16, 1994.

11) 河川生態学術研究会木津川研究グループ, 木津川の総合研 究II, pp.7-13, 2009.

12) 白旗清伸, 吉田浩義, 中井智司, 細見正明, 村上昭彦 : 河 口域の干潟における脱窒能の評価, 水環境学会誌, 第24巻, 第11号, pp.773-777, 2001.

13) Madsen, P.P.: Seasonal variation of denitrification rate in sedimentdetermined by use of 15N. Water Res., 13, pp.461-465, 1979.

14) 清家泰 : 汽水湖・中海における窒素代謝 I-夏期における底 泥表層部での脱窒特性，陸水学会誌Vol.47, pp.133-141, 1986.

(2010. 9. 30受付) 